\title{
Removal of lead (II) and copper (II) ions from aqueous solution by baobab (Adononsia digitata) fruit shells biomass
}

\author{
F. Chigondo ${ }^{1}$, B.C. Nyamunda ${ }^{1}$, S.C. Sithole ${ }^{1}$, L. Gwatidzo ${ }^{2}$ \\ ${ }^{1}$ (Department of Chemical Technology, Midlands State University, Zimbabwe) \\ ${ }^{2}$ (Department of Chemistry, Bindura University of Science Education, Zimbabwe)
}

\begin{abstract}
High concentration of heavy metals in the environment can be detrimental to a variety of living species. The purpose of this research was to explore the use of baobab (Adsononsia digitata) fruit shells in the removal of lead(II) and copper(II) ions from aqueous solutions. Batch experiments were conducted to determine the effect of varying adsorption parameters on the removal of aqueous lead and copper ions. The adsorption of $\mathrm{Pb}(\mathrm{II})$ was found to be maximum at $\mathrm{pH} 5.5$ using adsorbent dose of $0.7 \mathrm{~g}$. The adsorption of $\mathrm{Cu}(\mathrm{II})$ was found to be optimum at pH 6 using adsorbent dosage of $0.9 \mathrm{~g}$. The adsorption data conformed to Langmuir, Freundlich and Temkin isotherms. However the Temkin isotherm showed the best fitting model with highest $R^{2}$ values for both lead and copper (0.9977 and 0.9967) respectively. Baobab fruit shells can be used as a cost effective adsorbent for the removal of lead(II) and copper(II) ions from aqueous solutions in the treatment of industrial effluent.
\end{abstract}

Keywords: Adsorption, baobab, biosorbent, copper, isotherm, lead

\section{Introduction}

Rapid industrialization has led to increased disposal of heavy metals and radio nuclides into the environment. The industries mainly responsible for the discharge of waste water containing metals are mining and mineral processing, pigment manufacture, painting and photographic industry, metal working and finishing processes [1]. Since metals are non-biodegradable and may bioaccumulate in living tissues [2], their removal from the waste waters is nowadays legally imposed. Removal of heavy metals and radio nuclides from metalbearing wastewater is usually achieved by physico-chemical processes before discharging the effluents into natural water-body systems. Physico-chemical processes include precipitation, coagulation, reduction [3], ion exchange [4], membrane processes (ultrafiltration, electrodialysis and reverse osmosis) and adsorption [5].

These techniques have inherent limitations such as sensitive operating conditions, low metal removal efficiency and production of secondary sludge which is costly to dispose [6]. Adsorption has been shown to be the most promising option for the removal of metal ions from aqueous streams. Activated carbon is the most commonly used adsorbent for adsorption due to its effectiveness and versatility [7, 8]. However the high cost of activated carbon limits its use in adsorption.

The need for more economical and effective methods for the recovery of metal ions from wastewater have resulted in the development of alternative separation technologies. One such alternative process is biosorption, which utilizes various natural materials of biological origin such as bacteria, fungi, yeast and algae.

These biosorbents possess metal sequestering properties and can be used to reduce the concentration of heavy metal ions from ppm to ppb level [9]. Biosorbents which have been previously used include palm-nut shell [10] groundnut hull [11], Bambara groundnuts hulls [12] and sunflower husk [13].

This research focuses on the use of baobab shells as a biosorbent for the removal of lead and copper ions from waste water. Baobab fruit shells have no economic benefit. To the best of our knowledge there is no evidence in literature showing the use of baobab shells as a biosorbent for removal of lead and copper ions.

\section{Method}

\subsection{Preparation and preservation of the baobab fruit shells}

The baobab fruit shells (BFS) were rinsed with distilled water to remove dust and impurities deposited on the surface. The BFS were air-dried and then oven dried at $80^{\circ} \mathrm{C}$ to constant mass. The dried shells were pulverized and sieved to obtain particle sizes less than $300 \mu \mathrm{m}$. The baobab shell powder was soaked in $0.1 \mathrm{M}$ $\mathrm{HNO}_{3}$ for $24 \mathrm{~h}$. Acid treatment was done to remove or mask functional groups and to expose more ion binding sites. The mixture was filtered and the powder residue washed with distilled water several times to remove any acid contents. The filtered biomass was dried in an oven at $105^{\circ} \mathrm{C}$. The dried biomass was preserved in air-tight glass bottles to protect it from moisture [11]. 


\subsection{Characterisation of biosorbent}

Functional group elucidation was done using Fourier Transmitter Infrared (FTIR) spectrometer (Digilab Merlin 2000 series). Characterisation of the treated biomass was done before and after metal adsorption.

\subsection{Equilibrium adsorption studies}

\subsubsection{Effect of $\mathbf{p H}$}

The effect of $\mathrm{pH}$ on metal adsorption was monitored over a $\mathrm{pH}$ range of 2 to 6.5. In this study, $100 \mathrm{ml}$ of separate solutions ( $25 \mathrm{ppm} \mathrm{Pb}^{2+}$ and $8 \mathrm{ppm} \mathrm{Cu}^{2+}$ ions) were transferred into $250 \mathrm{ml}$ conical flasks agitated at $200 \mathrm{rpm}$ for $150 \mathrm{~min}$ with $0.5 \mathrm{~g}$ biosorbent. The mixtures were filtered and the filtrate analysed for residual metal ions using FAAS (Shimadzu 50 B).

\subsubsection{Effect of contact time}

The investigation was done to determine the optimum time for adsorption of both lead and copper ions using the baobab fruit shells. The biosorbent $(0.5 \mathrm{~g})$ was contacted with $100 \mathrm{ml}$ separate solutions of 25 ppm $\mathrm{Pb}^{2+}$ and $8 \mathrm{ppm} \mathrm{Cu}^{2+}$ ions adjusted to $\mathrm{pH} 5.5$ and 6 respectively. The solutions were agitated at $200 \mathrm{rpm}$ for different contact times (10-150 min). The mixtures were filtered and residual metal ions in filtrate analysed using FAAS.

\subsubsection{Effect of biosorbent dosage}

The effect of quantity of the baobab fruit shells used was investigated by equilibrating separate $100 \mathrm{ml}$ solutions of lead $(25 \mathrm{ppm})$ and copper $(8 \mathrm{ppm})$ ions with different masses of the adsorbent $(0.1-0.9 \mathrm{~g})$ agitated at $200 \mathrm{rpm}$ for $120 \mathrm{~min}$. The mixture was filtered and the residual metal ions in filtrate analysed using FAAS.

\subsubsection{Effect of initial metal concentration on monosorption}

Separate $100 \mathrm{ml}$ solutions of copper and lead ions with different initial concentrations (10-100 ppm) were contacted with optimised adsorbent dosage $(0.7 \mathrm{~g}$ for $\mathrm{Cu}$ at $\mathrm{pH} 5.5$ and $0.9 \mathrm{~g}$ for $\mathrm{Pb}$ at $\mathrm{pH} 6)$. The mixtures were agitated at $200 \mathrm{rpm}$ for $200 \mathrm{~min}$. The mixtures were filtered and filtrate analysed for residual metal ions.

\subsubsection{Effect of initial metal concentration on binary sorption}

The effects of initial concentrations of $\mathrm{Pb}^{2+}$ and $\mathrm{Cu}^{2+}$ ions in binary sorption were carried out at optimised adsorbent dose, contact time and $\mathrm{pH}$ by varying the initial metal ion concentration in the ratio 1:2.

The conical flasks were agitated at $200 \mathrm{rpm}$ for $120 \mathrm{~min}$. The mixtures were filtered and filtrate analysed for residual lead and copper ions using FAAS.

\subsection{FTIR characterisation}

\section{Results and Discussion}

The FTIR spectra of BFS before and after biosorption are shown in Figs. 1 and 2 respectively. The $\mathrm{OH},-\mathrm{NH}$, carbonyl and carboxylic groups are important sorption sites. The peak at $3420 \mathrm{~cm}^{-1}$ is attributed to $\mathrm{OH}$ and $-\mathrm{NH}$ groups. The absorption peaks between 1760 and $1600 \mathrm{~cm}^{-1}$ are characteristics of carbonyl groups stretching. The presence of $-\mathrm{OH}$ group, coupled to carbonyl group confirms the presence of carboxylic acid groups in the biosorbent [11]. The peaks around $1440 \mathrm{~cm}^{-1}$ indicate the presence $\mathrm{CH}_{2}$ and $\mathrm{CH}_{3}$ groups while peaks around $1420 \mathrm{~cm}^{-1}$ can be attributed to the aromatic $\mathrm{CH}$ and carboxyl-carbonate structures.

After biosorption, the broadening of $-\mathrm{OH}$ peak at $3420 \mathrm{~cm}^{-1}$ and carbonyl groups at $1640 \mathrm{~cm}^{-1}$ was observed (Fig. 2). This indicates the participation of hydroxyl and carbonyl groups in the biosorption of lead(II) and copper(II) ions. Similar spectra were obtained for biosorption studies of metal ions using groundnut hull [11], cashew nut shells [14] and palm nut shells [10].

\subsection{Equilibrium studies on biosorption of $\mathrm{Pb}^{2+}$ and $\mathrm{Cu}^{2+}$ 3.2.1 Effect of $\mathrm{pH}$}

The effect of $\mathrm{pH}$ on the adsorption of lead(II) and copper(II) ions is shown in Fig. 3. The uptake and equilibrium sorption capacity of metal removal from aqueous solution are strongly affected by the $\mathrm{pH}$ [15]. At the same time, the state of chemically active sites is changed by the solution $\mathrm{pH}$ [11]. The maximum adsorption of lead(II) and copper(II) ions was achieved at $\mathrm{pH} 5.5$ and 6 respectively. At $\mathrm{pH}$ values higher than 6.5 , both metals ions were precipitated. Therefore the removal of metal ions at higher $\mathrm{pH}$ values is due to the formation of precipitates rather than adsorption [16]. The biosorption capacity $\left(\mathrm{Q}_{\mathrm{e}}\right)$ increased with increase in $\mathrm{pH}$ up to $\mathrm{pH}$ 5.5 for lead(II) ions and $\mathrm{pH} 6$ for copper(II) ions. The increase in metal adsorption with increase in $\mathrm{pH}$ is due to a decrease in competition between hydrogen ions and metal ions for the surface sites and also due to decrease in positive surface charge. 


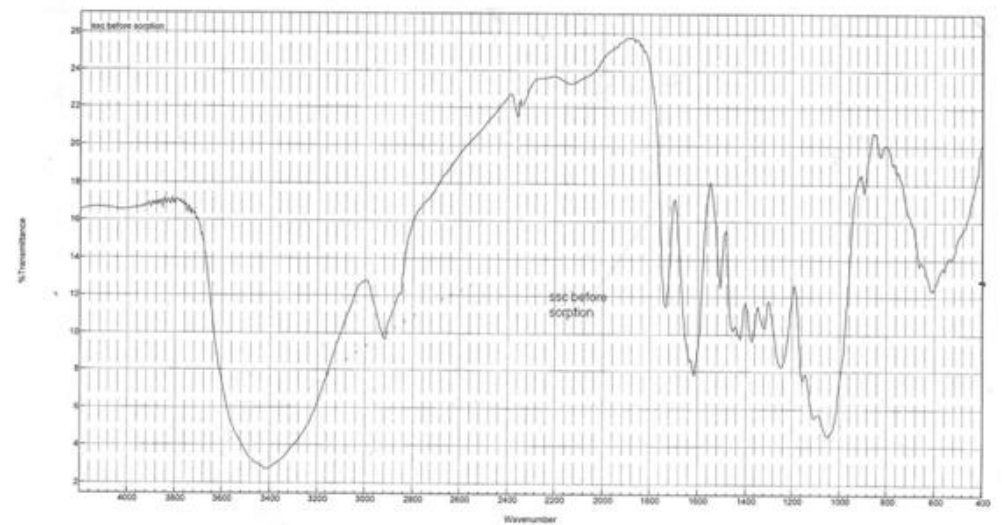

Figure 1: FTIR spectra of baobab fruit shells before biosorption

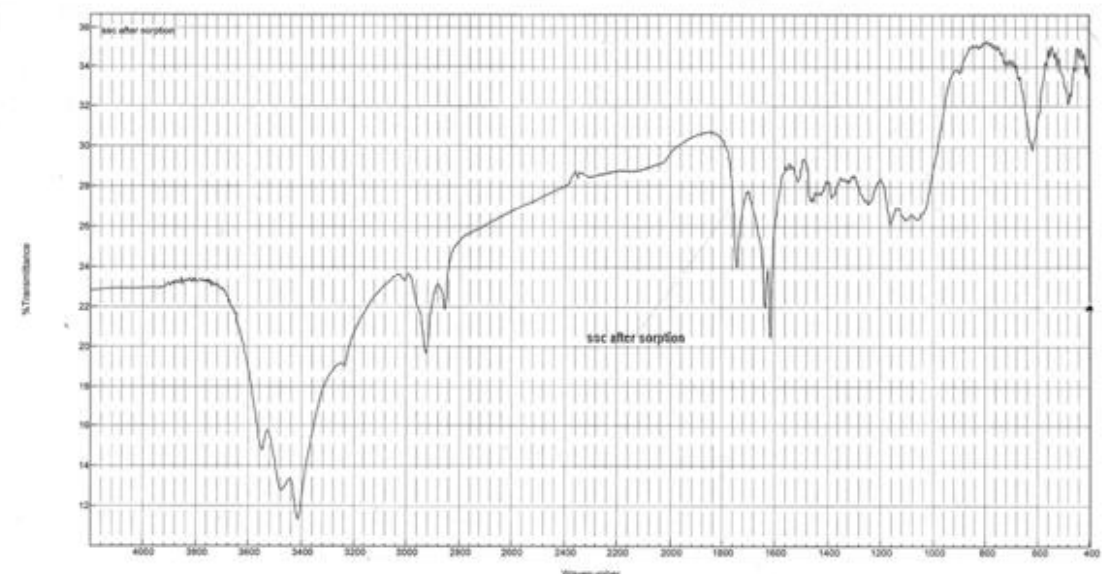

Figure 2: FTIR spectra of baobab fruit shells after biosorption

As the $\mathrm{pH}$ increases, more negatively charged surface becomes available thus facilitating greater metal adsorption. At low $\mathrm{pH}$, higher concentration and mobility of $\mathrm{H}^{+}$ions favour $\mathrm{H}^{+}$adsorption compared to metal ions. According to Onundi et al. [17] metal ions are more soluble in solution at lower pH values and this reduces their adsorption. At lower $\mathrm{pH}$, the surface of the adsorbent is surrounded by hydronium ions $\left(\mathrm{H}^{+}\right)$ thereby blocking metal ions from binding sites on adsorbents.

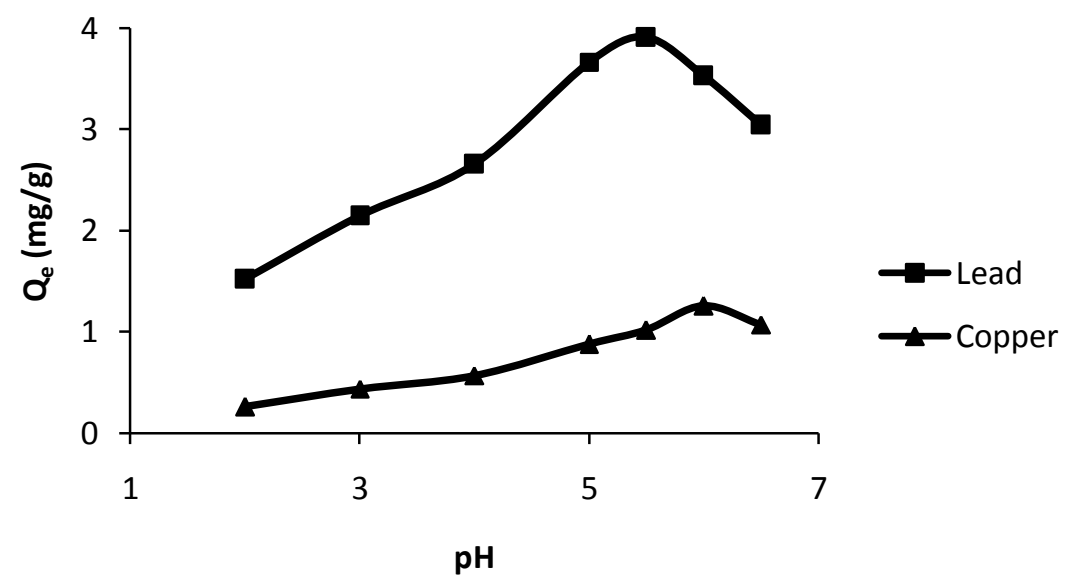

Figure 3: Effect of $\mathrm{pH}$ on the sorption of $\mathrm{Cu}^{2+}$ and $\mathrm{Pb}^{2+}$ ions 


\subsubsection{Effect of contact time}

The effect of contact time on the biosorption of lead(II) and copper(II) is shown in Fig. 4. The amount of the adsorbed metal ions increases with increasing time until it levels off after some $\left(90 \mathrm{~min}\right.$ for $\mathrm{Cu}^{2+}$ and 120 min for $\mathrm{Pb}^{2+}$ ). A constant adsorption is indicative of equilibration due to saturation of adsorption sites. Rapid adsorption of metal ions during the initial stages was due to the large initial concentration gradient between the adsorbate in solution and the number of available vacant sites on the adsorbent surface. The adsorption capacity for $\mathrm{Cu}^{2+}$ was lower than for $\mathrm{Pb}^{2+}$ ions.

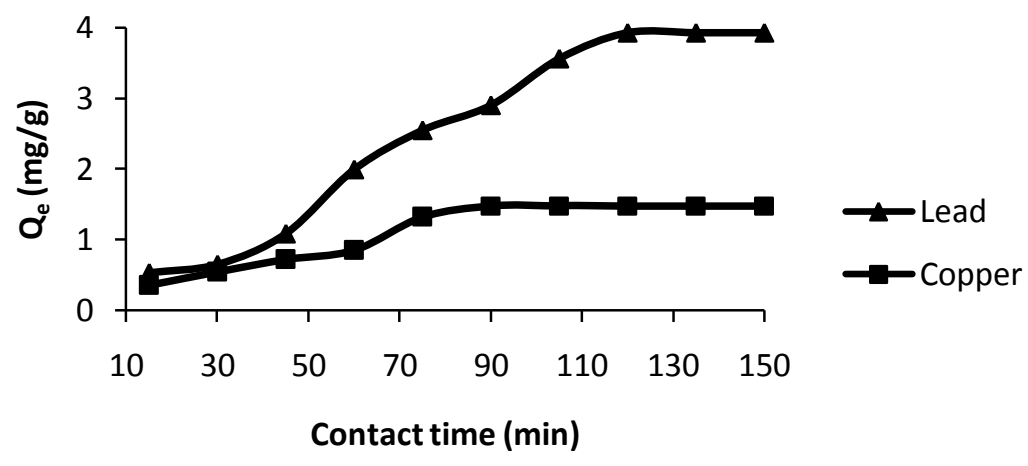

Figure 4: Effect of contact time on the sorption of $\mathrm{Cu}^{2+}$ and $\mathrm{Pb}^{2+}$ ions

\subsubsection{Effect of biosorbent dosage}

The effect of adsorbent dosage on the adsorption of lead(II) and copper(II) is shown in Fig. 5. There is an increase in adsorption capacity with increasing adsorbent dosage up to a maximum of $0.9 \mathrm{~g}$ for $\mathrm{Cu}$ and $0.7 \mathrm{~g}$ for $\mathrm{Pb}$ giving corresponding maximum percentage metal removal of 78 and $68 \%$ respectively. Further increment in adsorbent dosages resulted in decline in adsorption capacity. The initial increase in adsorption capacity with increasing adsorbent dosage is explained by the increase in the number of exchangeable sites for metal ion adsorption [17]. The decline in adsorption beyond certain adsorbent dosages could be due to the aggregation/agglomeration of sorbent particles at higher dosages which would lead to a decrease in the total surface area of the adsorbent particles available to the metal ions. As a result the adsorption capacity of the adsorbent is not fully utilised [18].

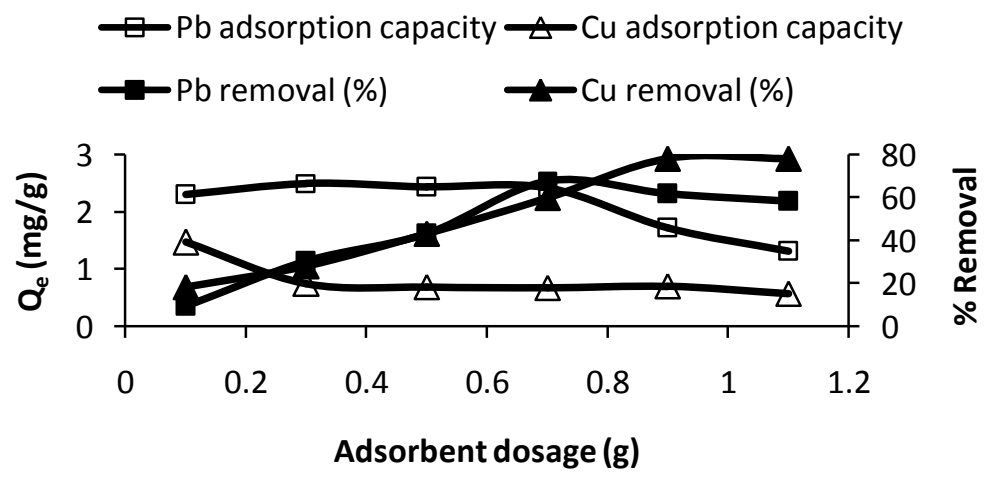

Figure 5: Effect of adsorbent dosage on adsorption of $\mathrm{Cu}^{2+}$ and $\mathrm{Pb}^{2+}$ ions

\subsubsection{Effect of initial metal concentration on monosorption}

The effect of initial concentration on the monosorption of copper and lead ions is shown in Fig. 6. For both metal ions, an increase in initial concentration resulted in increase in the adsorption capacity. This can also be explained in terms of increase in adsorption sites coverage as the metal ion concentration is increased [19].

High metal concentration saturates the adsorbent sites more quickly thereby decreasing the overall percentage metal removal. A similar trend was observed by Andal and Sakthi [20]. 


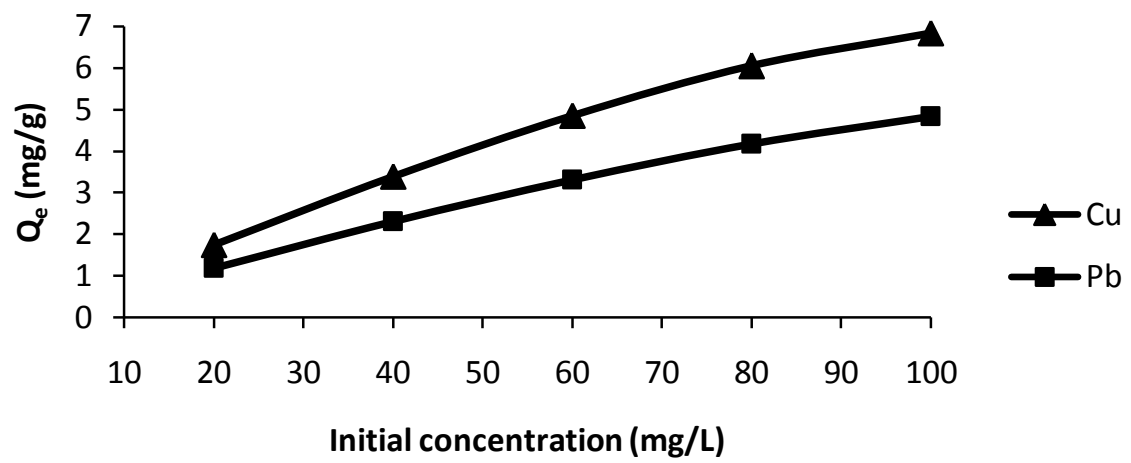

Figure 6: Effect of initial metal ion concentration on adsorption capacity

\subsection{Adsorption isotherms}

The Langmuir (eqn 1), Freundlich (eqn 2) and Temkin (Eqn 3) isotherms were applied to the equilibrium studies to test for data conformity. The linear forms of the isotherms are represented by equations 13.

$\frac{1}{q_{e}}=\frac{1}{Q}+\frac{1}{b Q} * \frac{1}{C_{e}}$

Where, $\mathrm{Q}\left(\mathrm{mgg}^{-1}\right)$ and $\mathrm{b}\left(\mathrm{Lmg}^{-1}\right)$ are the Langmuir constants related to the maximum adsorption and energy of adsorption respectively and $\mathrm{C}_{\mathrm{e}}$ is the equilibrium concentration of the adsorbate $\left(\mathrm{mgL}^{-1}\right)$.

$\log \mathrm{q}_{\mathrm{e}}=\log \mathrm{K}+\frac{1}{\mathrm{n}} \log \mathrm{C}_{\mathrm{e}}$

Where, $\mathrm{k}$ and $1 / \mathrm{n}$ are the Freundlich constants related to adsorption capacity and adsorption intensity respectively of the adsorbent.

$\mathrm{X}=\mathrm{a}+\mathrm{b} \ln \mathrm{C}$

Where, $\mathrm{C}$ is the concentration of the adsorbate in solution at equilibrium $\left(\mathrm{mgL}^{-1}\right), \mathrm{X}$ is the amount of metal adsorbed per unit weight of adsorbent $\left(\mathrm{mgg}^{-1}\right)$, a and $\mathrm{b}$ are constants related to adsorption capacity and intensity of adsorption.

It was observed that the Langmuir adsorption isotherm satisfactorily describes the sorption of copper and lead ions from aqueous solutions using baobab shells as indicated by the high correlation coefficients $\left(\mathrm{R}^{2}\right)$ of 0.9949 and 0.9961 respectively (Fig. 7). The applicability of the Langmuir isotherm indicates good monolayer coverage of lead(II) and copper(II) ions on the surface of baobab shells which consequently suggests the formation of a mono layer on the adsorbent surface in the given concentration range [21]. The fact that the Langmuir isotherm fits the experimental data very well may be due to the homogenous distribution of active sites on the adsorbent since the Langmuir equation assumes that the surface is homogenous. Thus the applicability of the Langmuir isotherm in the present system indicates the monolayer coverage of lead(II) and copper(II) ions on the outer surfaces of the adsorbent [19]. The calculated model parameters with correlation coefficients are shown in Table 1 . The adsorption capacity, $\mathrm{Q}_{\max },\left(\mathrm{mgg}^{-1}\right)$ of copper is higher than that of lead.

The affinity of the two metals for the adsorbent surface in terms of $b$ is higher for lead. The values of $b$ were fairly low which implies low surface energy in the process and consequently low bonding between metal ions and the baobab fruit shells. Qaiser et al. [11] reported the maximum adsorption capacities for lead on groundnut hull $\left(31.54 \mathrm{mgg}^{-1}\right)$ and baggase fly ash $\left(2.5 \mathrm{mgg}^{-1}\right)$.

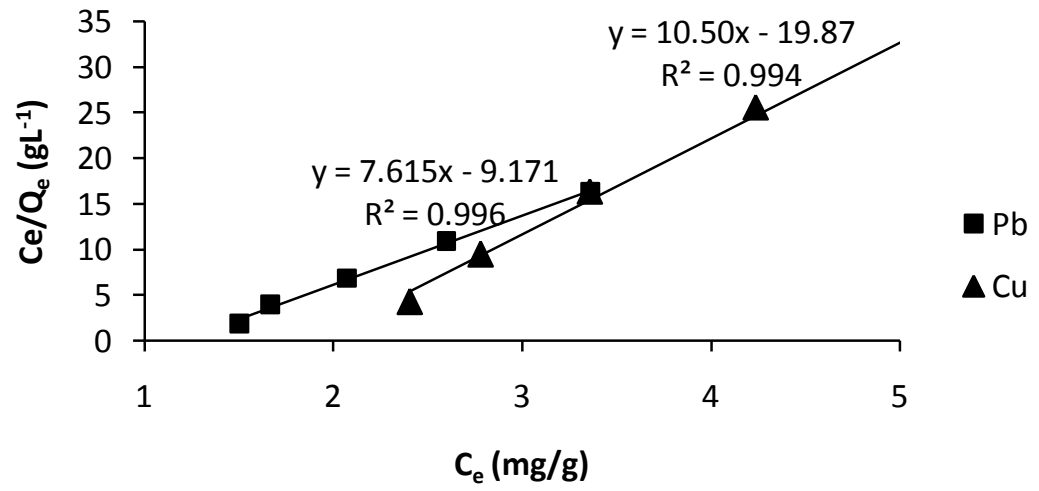

Figure 7: Langmuir isotherm for the adsorption of $\mathrm{Pb}^{2+}$ and $\mathrm{Cu}^{2+}$ on shells of baobab 
The Freundlich isotherms for lead and copper adsorption are shown in Fig. 8. It was observed that the Freundlich adsorption isotherm also conforms to the sorption of lead and copper ions from aqueous solutions using baobab fruit shells. However, the level of conformity is to a less extent compared to the Langmuir adsorption isotherms as indicated by lower correlation coefficients values of 0.9755 and 0.973 for $\mathrm{Pb}^{2+}$ and $\mathrm{Cu}^{2+}$ respectively. The values of $\mathrm{n}(1.57$ and 1.61) for lead and copper respectively, confirm that the baobab shells have a heterogeneous surface since the values satisfy the heterogeneity condition where $\mathrm{n}$ must be in the range 1 $<\mathrm{n}<10$ [22]. The values of $1 / \mathrm{n}$ ranging from 0 to 1 are a measure of adsorption intensity or surface homogeneity as the values approach zero. Values for $1 / \mathrm{n}$ less than 1 indicate normal Langmuir adsorption isotherm while those values above 1 are indicative of cooperative adsorption [23]. The values of $K_{F}$ for lead (0.95) and copper (0.90) imply that there was low uptake of the metal ions onto the adsorbent surface.

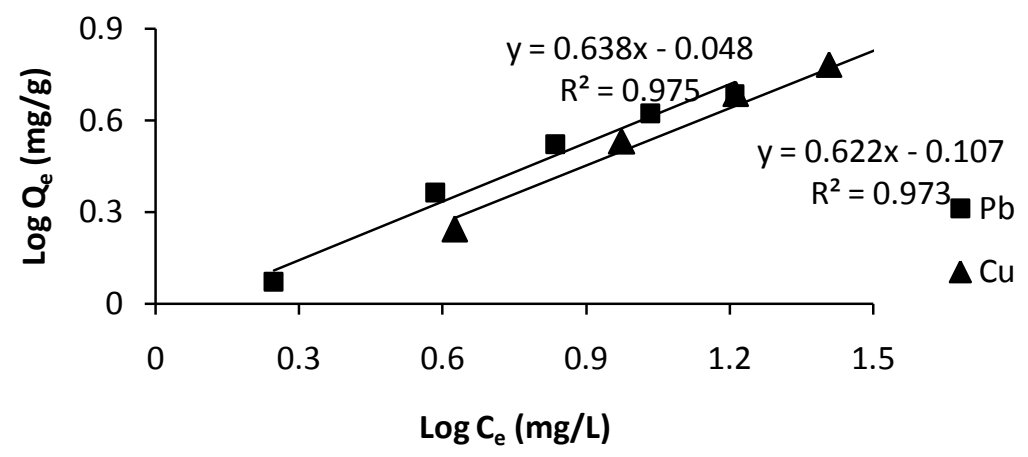

Figure 8: Freundlich isotherms for the adsorption of $\mathrm{Pb}^{2+}$ and $\mathrm{Cu}^{2+}$ on shells of baobab

Table 1: Isotherm model parameters

\begin{tabular}{|c|c|c|c|}
\hline Model & Parameter & $\mathrm{Pb}$ & $\mathrm{Cu}$ \\
\hline \multirow{3}{*}{ Langmuir } & $\mathrm{Q}_{\max }$ & 7.65 & 10.56 \\
\cline { 2 - 4 } & $\mathrm{b}$ & 0.11 & 0.05 \\
\cline { 2 - 4 } & $\mathrm{R}_{\mathrm{L}}$ & 0.48 & 0.50 \\
\cline { 2 - 4 } & $\mathrm{R}^{2}$ & 0.9961 & 0.9949 \\
\hline \multirow{4}{*}{ Freundlich } & $\mathrm{K}_{\mathrm{f}}$ & 0.95 & 0.90 \\
\cline { 2 - 4 } & $\mathrm{n}$ & 1.57 & 1.61 \\
\cline { 2 - 4 } & $\mathrm{R}^{2}$ & 0.9755 & 0.9730 \\
\hline \multirow{3}{*}{ Temkin } & $\mathrm{K}_{\mathrm{T}}$ & 1.04 & 1.37 \\
\cline { 2 - 4 } & $\mathrm{b}_{\mathrm{T}}$ & 645.59 & 0.9967 .34 \\
\cline { 2 - 4 } & $\mathrm{R}^{2}$ & 0.9977 & \\
\cline { 2 - 4 } & & & \\
\hline
\end{tabular}

Fig. 9 shows the Temkin isotherms for the adsorption of copper and lead. The Temkin isotherm takes into account the occupation of the more energetic adsorption sites [24]. Of the three isotherms under consideration, the Temkin adsorption isotherm best describes the sorption of lead and copper ions from aqueous solutions using baobab shells as indicated by the highest correlation coefficients of 0.9977 and 0.9967 for lead and copper respectively and $b_{\mathrm{T}}$ values of $645.59 \mathrm{KJmol}^{-1}$ and $457.34 \mathrm{KJmol}^{-1}$ respectively. The intensity of sorption $\left(\mathrm{K}_{\mathrm{T}}\right)$ and the heat of sorption $\left(\mathrm{b}_{\mathrm{T}}\right)$ for lead and copper confirm further that the data best fit the Temkin isotherm.

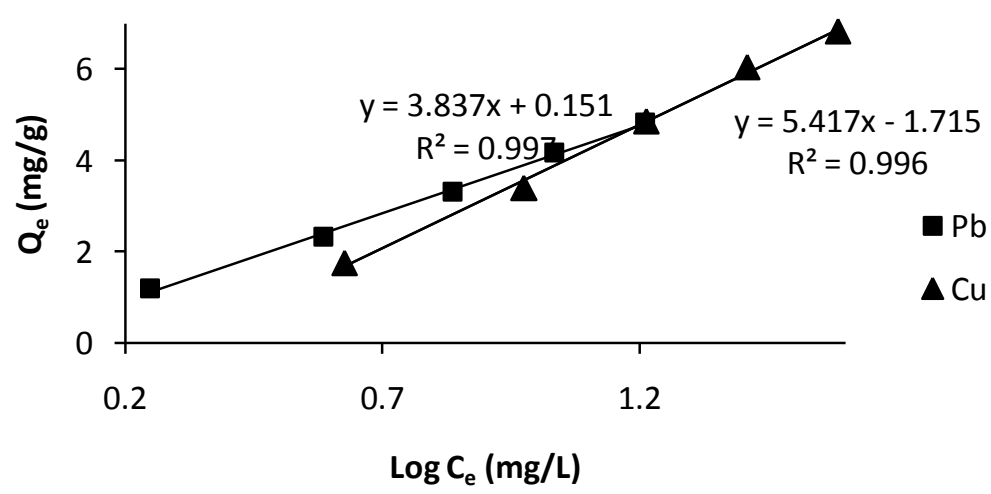

Figure 9: Temkin isotherms for the adsorption of $\mathrm{Pb}^{2+}$ and $\mathrm{Cu}^{2+}$ on shells of baobab 


\subsubsection{Effect of initial metal concentration on binary sorption}

The $\mathrm{Cu}-\mathrm{Pb}$ binary competitive sorption was tested by the Langmuir model as shown in Figs. 10 and 11. The binary combination in which copper was the primary ion $(\mathrm{Cu}-\mathrm{Pb})$ fitted the competitive Langmuir model better than that for lead as indicated by a higher correlation coefficient value. The results indicate that there is competitive interaction in sorption of $\mathrm{Cu}^{2+}$ and $\mathrm{Pb}^{2+}$ in the binary system.

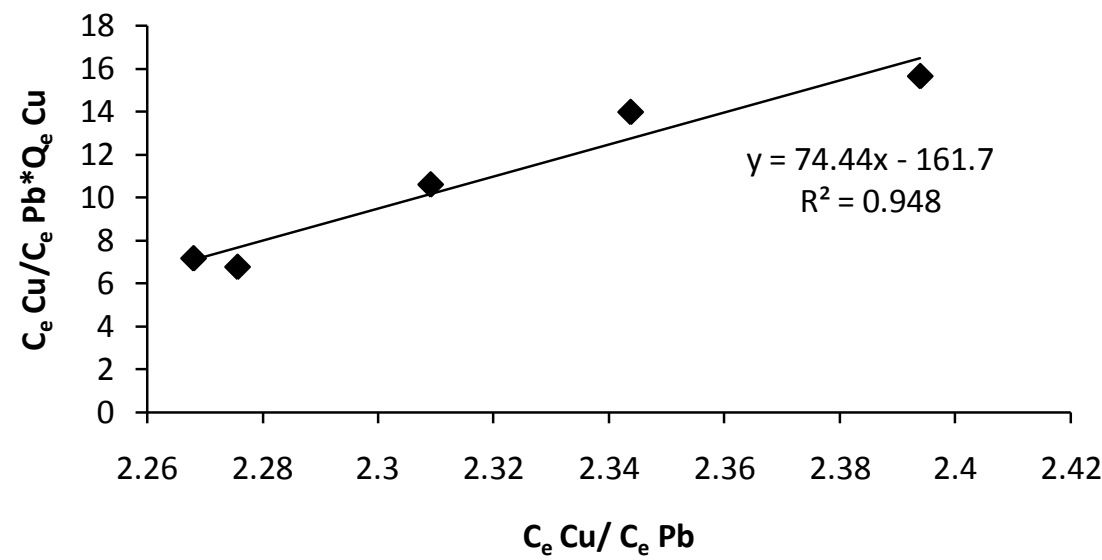

Figure 10: Cu-Pb binary sorption on baobab fruit shells

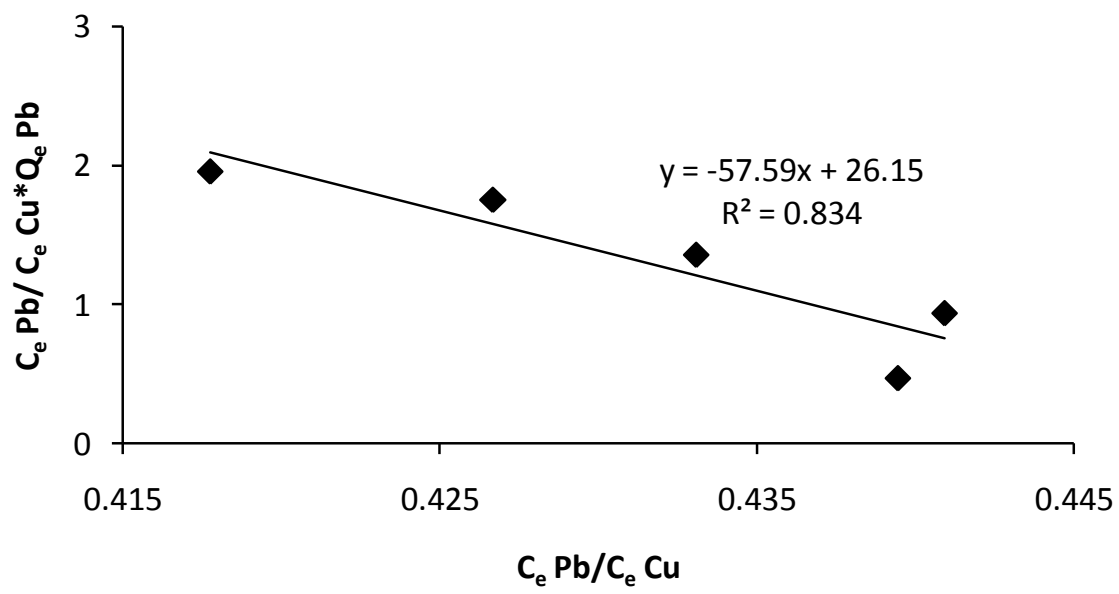

Figure 11: Pb-Cu binary sorption on baobab fruit shells

The effectiveness of baobab shells was compared to other biosorbents reported in literature (Table 2). It appears that BFS adsorb lead and copper quite well.

Table 2: Comparison of $\mathbf{Q}_{\max }$ of baobab fruit shells with other biosorbents

\begin{tabular}{|l|c|c|c|}
\hline \multirow{2}{*}{ Biosorbent } & \multicolumn{2}{|c|}{$\mathrm{Q}_{\max }(\mathrm{mg} / \mathrm{g})$} & \multirow{2}{*}{ Reference } \\
\cline { 2 - 4 } & $\mathrm{Pb}$ & $\mathrm{Cu}$ & {$[25]$} \\
\hline Crab fish & 19.83 & - & {$[11]$} \\
\hline Groundnut hull & 31.54 & - & {$[17]$} \\
\hline Palm shell & 1.34 & 1.58 & {$[20]$} \\
\hline Bombax ceiba saw dust & 40.49 & & Current study \\
\hline Baobab shells & 7.65 & 10.56 & \\
\hline
\end{tabular}

\section{Conclusion}

This study has demonstrated that baobab fruit shells has favourable properties for the biosorption of lead and copper ions from aqueous solutions and the adsorbent properties are enhanced by acid treatment. The biosorption of lead and copper ions was highly dependent on experimental parameters such as contact time, initial metal concentration, $\mathrm{pH}$ and adsorbent dosage. The adsorption of $\mathrm{Pb}(\mathrm{II})$ was found to be optimum at $\mathrm{pH}$ 5.5 , adsorbent dose of $0.7 \mathrm{~g}$, metal ion concentration of $10 \mathrm{ppm}$ and contact time of $120 \mathrm{~min}$. The adsorption of $\mathrm{Cu}$ (II) was found to be optimum at pH 6, adsorbent dose of $0.9 \mathrm{~g}$, metal ion concentration of $20 \mathrm{ppm}$ and contact time of $120 \mathrm{~min}$. The Temkin fitted best to the adsorption data. There is need for further studies to investigate 
the use of baobab fruit shells in treating industrial effluent. This could be a cost effective method of utilising waste baobab fruit shells in removing lead and copper from industrial wastewater.

\section{References}

[1] N.A. Babarinde, J.O. Babalola, and A.R.A. Sanni, Biosorption of lead ions from aqueous solutions by maize leaf, International Journal of Physical Sciences, 1(1), 2006, 23-26.

[2] P.A. Maryan, H.M. Pinheiro, J.A. Teiseira, and M.F. Rosa, Removal efficiency of $\mathrm{Cu}(\mathrm{II}), \mathrm{Cd}(\mathrm{II})$ and $\mathrm{Pb}(\mathrm{II}) \mathrm{by}$ waste brewery biomass, $\mathrm{pH}$ and cation association effects, Desalination Journal, 124, 2007,137-144.

[3] S.D. Kim, K.S. Park, and M.B. Gu, Toxicity of hexavalent chromium to Daphnia magna: influence of reduction reaction by ferrous iron, Journal of Hazardous Materials, 93(2), 2002, 155-164.

[4] A.B. Paknikar, A. Ballester, F. Gonzalez, M.L. Blazquez, J.A. Murioz, J. Saez, and M. Zapata, Study of cadmium, zinc and lead biosorption by orange wastes using the subsequent addition method, Bioresources Technology Journal, 99(17), 2003, 8101-8106.

[5] C.L. Ake, K. Mayura, H. Huebner, G.R. Bratton, and T.D. Phillips, Development of porous clay based composites for the sorption of lead from water, Journal of Toxicology Environmental Health Part A 63 (6), 2001, 459-4759.

[6] J.C. Ingwe, O.F. Mbonu, and A.A. Abia, Sorption Kinetic, Interparticle Diffusion and Equilibrium Partitioning of Azo Dyes on Great Millet (Andropogon Sorghum) Waste Biomass, Journal of Applied Sciences, 7(19), 2007, 2840-2847.

[7] Z. Asku, Application of biosorption for the removal of organic pollutants: a review, Process Biochemistry, 40, 2009, 997-10268

[8] M. Lotfi, and N. Adhoum, Modified activated carbon for the removal of copper, zinc, chromium and cyanide from wastewater, Separation and Purification Technology, 26 ( 2-3), 2002, 137-146.

[9] C.D. Elcey, and B. Manoj, Demineralization of Coal by Stepwise Bioleaching: A study of sub-bituminous Indian coal by FTIR and SEM, Journal of the University of Chemical Technology and Metallurgy, 45 (4), 2010, 385-390.

[10] Y.B. Onundi, A.A. Mamun, M.F. Al Khatib, and Y.M. Ahmed, Adsorption of copper, nickel and lead ions from synthetic semiconductor industrial wastewater by palm shell activated carbon, International Journal of Environmental Science and Technology, 7(4), 2010, 751-758.

[11] S. Qaiser, R. Anwar, and U. Muhammad, Biosorption of lead (II) and chromium(VI) on groundnut hull: Equilibrium, kinetics and thermodynamics study, Electronic Journal of biotechnology, 12(4), 2009, 1-4.

[12] E. Sebata, M. Moyo, U. Guyo, N.P. Ngano, B.C. Nyamunda, F. Chigondo, V. Chitsa, and M. Shumba. Adsorptive Removal of Atrazine from Aqueous Solution Using Bambara Groundnut Hulls (Vigna Subterranean), International Journal of Engineering Research \& Technology, 2(5), 2013, 312-321.

[13] M. Moyo, A. Maringe, F. Chigondo, B.C. Nyamunda, E. Sebata, M. Shumba, Adsorptive Removal of Nitrate Ions from Aqueous Solutions Using Acid Treated Sunflower Seed Husk (Helianthus annuus), International Journal of Advances in Science and Technology, 5 (6), 2012, 47-66.

[14] S. Tangjuank, N. Insuk, J. Tontrakoon, and V. Udeye, Adsorption of lead(II) and cadmium(II) ions from aqueous solutions by adsorption on activated carbon prepared from cashew nut shells, World Academy of Science, Engineering and Technology, 6(2), 2009, 298-306.

[15] C.M. Zvinowanda, O.J. Okonkwo, M.M. Sekhula, N.M. Agyei, and R. Sadiku, Application of maize tassel for the removal of Pb, $\mathrm{Se}, \mathrm{Sr}, \mathrm{U}$ and $\mathrm{V}$ from borehole water contaminated with mine wastewater in the presence of alkaline metals, Journal of Harzadous Materials, 2009, 164, 884-891.

[16] B. Bayat, Comparative study of adsorption properties of Turkish fly ashes 1. The case of Nickel(II), Copper(II) and Zinc(II), Journal of Hazardous Materials, 144, 2002, 251-273.

[17] Y.B. Onundi, A.A. Mamun, M.F. Al Khatib, and Y.M. Ahmed, 2010, Adsorption of copper, nickel and lead ions from synthetic semiconductor industrial wastewater by palm shell activated carbon, International Journal of Environmental Science Technology, 7(4), 2010, 751-758.

[18] N.M. Andal, and V. Sakthi, A comparative study on the sorption characteristics of Pb(II) and Hg(II) onto activated carbon, Journal of Chemistry, 7(3), 2010, 967-974.

[19] D.T. Najua, C.A. Luqman, Z. Zawani, and A.R. Suraya, Adsorption of copper from aqueous solution by Elais Guineensis kernel activated carbon, Journal of Engineering of Science and Technology, 2(1), 2008, 180-189.

[20] N. Sakthi, N. M. Andal, S. Rengaraj, and M. Sillanpää, Removal of Pb(II) ions from aqueous solutions using Bombax ceiba saw dust activated carbon. Desalination Water and Treatment, 16, 2010, 262-270.

[21] H. Ali, and S.K. Muhammad, Biosorption of crystal violet from water on leaf biomass of Calotropis procera, Journal of Environmental Science and Technology, 1(3), 2008, 143-150.

[22] M. Nadeem, A. Mahmood, S.A. Shalid, S.S. Shah, and A.M. Khalid., Sorption of lead from aqueous solution by modified carbon adsorbents, Journal of Hazardous Materials, 138(3), 2006, 604-613.

[23] M.J. Ketcha, M.H. Ngomo, D. Kouotou, and N.P. Tchoua, Kinetic and equilibrium studies of the adsorption of nitrate ions in aqueous solutions by activated carbons and zeolite, Resources Journal of Chemistry Environmental, 11(3), 2007, 47-49.

[24] N.T. Abdel-Ghani, M. Henfy, and G.A.F. El-Chaghaby, Removal of lead from aqueous solutions using low cost abundantly available adsorbents, International Journal of Environmental Science and Technology, 4(1), 2007, 67-73.

[25] S. Dahiya, R.M. Tripathi, and A.G. Hegde, Biosorption of lead and copper from aqueous solutions by pre-treated crab and arca shell biomass, Bioresource Technology, 99, 2008, 179-187. 